\title{
Upper Pliocene to Lower Pleistocene volcanic complexes and Upper Neogene deformation in the south-central Andes $\left(36^{\circ} 30^{\prime}-38^{\circ} \mathrm{S}\right)$
}

\author{
Fernando Miranda* \\ Servicio Geológico Minero Argentino, Julio A. Roca 651, Capital Federal, Argentina \\ Andrés Folguera \\ Laboratorio de Tectónica Andina, Universidad de Buenos Aires, Pabellón 2 Ciudad Universitaria, Capital Federal, Argentina \\ Pablo R. Leal \\ Cátedra de Mineralogía, Universidad de Buenos Aires, Pabellón 2 Ciudad Universitaria, Capital Federal, Argentina \\ José A. Naranjo \\ Servicio Nacional de Geología y Minería de Chile (SERNAGEOMIN, Chile), Av. Santa María 0104, Providencia, Santiago, Chile \\ Abel Pesce \\ Servicio Geológico Minero Argentino, Area de Geotermia, Julio A. Roca 651, Capital Federal, Argentina
}

\begin{abstract}
The Agrio $\left(37^{\circ} 51^{\prime} \mathrm{S}, 7^{\circ} 26^{\prime} \mathrm{W}\right)$, Vilú Mallín $\left(37^{\circ} 28^{\prime} \mathrm{S}, 7^{\circ} 45^{\prime} \mathrm{W}\right)$, Trohunco $\left(37^{\circ} 18^{\prime} \mathrm{S}, 7^{\circ} 01^{\prime} \mathrm{W}\right)$, Domuyo $\left(3^{\circ} 38^{\prime} \mathrm{S}, 7^{\circ} 26^{\prime} \mathrm{W}\right)$, and Los Cardos-Centinela $\left(37^{\circ} 06^{\prime} \mathrm{S}\right.$, $7^{\circ} 5^{\prime} \mathbf{W}$ ) volcanic complexes in Argentina are the principal Upper Pliocene to Lower Pleistocene volcanic complexes east of the Andean Main Cordillera and the modern Southern volcanic zone arc front. These complexes are part of the Upper Pliocene to Lower Pleistocene volcanic arc that was on the eastern flank of the Andes at that time. The volcanic rocks provide constraints on the age and style of Neogene deformation in the modern backarc between $36^{\circ} 30^{\prime}$ and $38^{\circ} \mathrm{S}$. New and published K-Ar ages along with stratigraphic and structural relations show that the region was affected by a late Miocene compressional deformation between 9 and 6.8 Ma. A more heterogeneous picture emerges for younger deformation in the region. The most important structures include a N-NW-trending contractional fault system that connects the Trohunco and Los Cardos-Centinela complex, and a NE-trending extensional fault system along which the Agrio caldera, Vilú Mallín, and Domuyo volcanic complexes are aligned. Overall, the backarc in this region was affected by compression in the late Miocene and extensional collapse and transpressional deformation due to strain partitioning in the late Pliocene to Quaternary.
\end{abstract}

Keywords: Upper Pliocene, Pleistocene volcanism, Southern volcanic zone, Patagonia, retroarc deformation.

\footnotetext{
*E-mail: fmiran@secind.mecon.gov.ar.
}

Miranda, F., Folguera, A., Leal, P.R., Naranjo, J.A., and Pesce, A., 2006, Upper Pliocene to Lower Pleistocene volcanic complexes and Upper Neogene deformation in the south-central Andes $\left(36^{\circ} 30^{\prime}-38^{\circ}\right.$ S), in Kay, S.M., and Ramos, V.A., eds., Evolution of an Andean margin: A tectonic and magmatic view from the Andes to the Neuquén Basin $\left(35^{\circ}-39^{\circ} \mathrm{S}\right.$ lat): Geological Society of America Special Paper 407, p. 287-298, doi: 10.1130/2006.2407(13). For permission to copy, contact editing@geosociety.org. (02006 Geological Society of America. All rights reserved. 


\section{INTRODUCTION}

The Southern volcanic zone between $33^{\circ}$ and $46^{\circ} \mathrm{S}$ occurs above a $30^{\circ}$ E-dipping segment of the subducting Nazca plate beneath the South American plate (e.g., Bohm et al., 2002). On a broad scale, volcanic rocks have been continuously generated along this segment since the early Miocene, when the trenchnormal component of subduction increased as a consequence of the breakup of the Farallon plate (Pardo Casas and Molnar, 1987). Among these volcanic rocks are series of stratovolcanoes, calderas, and other minor volcanic centers that have erupted in Pliocene to Holocene times (e.g., Muñoz and Stern, 1988). López-Escobar et al. (1995) and Lara et al. (2001), among many others, have studied the petrology, geochemistry, and host structure of the Upper Pleistocene to Holocene volcanic rocks in the Southern volcanic zone frontal arc region. Muñoz and Stern (1988) studied Upper Pliocene to Lower Pleistocene volcanic rocks east of the modern volcanic front south of $37.5^{\circ} \mathrm{S}$. In contrast, Upper Pliocene to Lower Pleistocene volcanic rocks east of the present volcanic front between $36.5^{\circ} \mathrm{S}$ and $38^{\circ} \mathrm{S}$ are just beginning to be studied in detail (e.g., Lara and Folguera, this volume, chapter 14; Kay et al., this volume, chapter 2; Varekamp, this volume, chapter 15; and references in these papers).

Published and new geochronological data on a series of stratovolcanoes, volcanic complexes, and calderas aligned in a narrow longitudinal band from $36^{\circ} 30^{\prime} \mathrm{S}$ to $38^{\circ} \mathrm{S}$ on the eastern side of the Andes indicate the presence of an Upper Pliocene to Lower Pleistocene extinct volcanic front (Muñoz and Stern, 1988; Muñoz Bravo et al., 1989), or at least a broadened one in comparison with the 2-0 Ma volcanic arc (Lara and Folguera, this volume, chapter 14). Unlike the centers at the arc front on the western side of the Andes, which are not associated with the
Pliocene-Pleistocene orogenic front, these Upper Pliocene to Lower Pleistocene volcanic centers are close to the emergent fold-and-thrust belt and provide a means to constrain the age of deformation in this part of the modern retroarc.

Llambías et al. (1978b), Pesce (1981, 1987), Brousse and Pesce (1982), Rovere (1993, 1998), Miranda (1996), Vattuone and Latorre (1998), and Ré et al. (2000) have presented petrological, geochemical, and geochronological studies of the volcanic rocks in these extinct retroarc centers. However, no integrated studies have been done at a regional scale with regard to: (1) the structures that host these volcanic rocks, (2) the effects of younger deformation on these centers, or (3) the temporal constraints that these volcanic rocks can place on earlier periods of deformation. The purpose of this paper is to describe and present maps of these centers, to discuss their ages and the deformation that affects them in the context of the new K-Ar ages in Table 1 and the fission-track ages in Table 2, and to put these centers into the context of the regional deformation pattern.

\section{GEOLOGICAL SETTING AND REGIONAL GEOLOGY}

The area under study is located in the transition between the southern Central Andes $\left(27^{\circ}-38^{\circ} \mathrm{S}\right)$ and the northern Patagonian Andes $\left(38^{\circ}-45^{\circ} \mathrm{S}\right)$ (Fig. 1). The southern Central Andes are characterized by a recent uplift history related to the Neogene stacking of crustal thrust sheets that have partially obliterated older deformational features (Ramos, 1999). In contrast, the deformation pattern of the northern Patagonian Andes to the south shows an evolution marked by periods of foreland progression of east-vergent Late Cretaceous to Upper Miocene thrusts (Ramos, 1977; Zapata et al., 1999; Zapata and Folguera, 2006), and little Upper Neogene to Quaternary exhumation in

TABLE 1. K-Ar AGES

\begin{tabular}{|c|c|c|c|c|c|c|c|c|}
\hline \multirow{2}{*}{$\begin{array}{l}\text { Isotopic age } \\
\text { (Ma) }\end{array}$} & \multirow[t]{2}{*}{ Method } & \multirow[t]{2}{*}{ Rock } & \multicolumn{4}{|c|}{ Analytical data } & \multirow[t]{2}{*}{ Location } & \multirow[t]{2}{*}{ Source } \\
\hline & & & $\begin{array}{c}\begin{array}{c}\text { K content } \\
(\%)\end{array} \\
\end{array}$ & $\begin{array}{c}{ }^{40} \mathrm{~K} \\
(\mathrm{~mol} / \mathrm{g})\end{array}$ & ${ }^{40} \mathrm{Ar}$ rad. & $\begin{array}{c}{ }^{40} \mathrm{Ar} \text { atm. } \\
(\%)\end{array}$ & & \\
\hline $6.8 \pm 0.4$ & $\mathrm{~K}-\mathrm{Ar}$ & Andesite & 0.881 & n.a. & $\begin{array}{c}0.232 \\
\mathrm{~nL} / \mathrm{g}\end{array}$ & 61 & Vilú Mallín caldera basement & $\begin{array}{l}\text { SERNAGEOMIN Proyecto Riesgo } \\
\text { Volcánico (2311) }\end{array}$ \\
\hline $3.1 \pm 0.2$ & $\mathrm{~K}-\mathrm{Ar}$ & Andesite & 0.944 & n.a. & $\begin{array}{l}0.116 \\
\mathrm{~nL} / \mathrm{g}\end{array}$ & 66 & $\begin{array}{l}\text { Vilú Mallín postcaldera } \\
\text { monogenic flow }\end{array}$ & $\begin{array}{c}\text { SERNAGEOMIN Proyecto Riesgo } \\
\text { Volcánico (2311) }\end{array}$ \\
\hline $4.0 \pm 0.5$ & $\mathrm{~K}-\mathrm{Ar}$ & Andesite & 1.098 & n.a. & $\begin{array}{c}0.169 \\
\mathrm{~nL} / \mathrm{g}\end{array}$ & 85 & Vilú Mallín precaldera sequence & $\begin{array}{c}\text { SERNAGEOMIN Proyecto Riesgo } \\
\text { Volcánico }(2311)\end{array}$ \\
\hline $2.5 \pm 0.5$ & $\begin{array}{c}\mathrm{K}-\mathrm{Ar} \\
\text { (whole rock) }\end{array}$ & Granophyre & 2.44 & $7.283 \times 10^{-8}$ & $\begin{array}{c}0.107 \times 10^{-10} \\
\mathrm{~mol} / \mathrm{g}\end{array}$ & 88 & Domuyo dome & Miranda (1996) \\
\hline $\begin{array}{l}10 \pm 1 \\
14 \pm 2\end{array}$ & $\begin{array}{c}\text { K-Ar } \\
\text { (whole rock) }\end{array}$ & Andesite & n.a. & n.a. & n.a. & n.a. & $\begin{array}{c}\text { Cajón Negro Fm. left side } \\
\text { Atreuco stream }\end{array}$ & Pesce $(1983,1987)$ \\
\hline $0.72 \pm 0.1$ & $\mathrm{~K}-\operatorname{Ar}(?)$ & Dacite & n.a. & n.a. & n.a. & n.a. & Dome (Mt. Domo) & Pesce $(1983,1987)$ \\
\hline $4.0 \pm 1.0$ & $\mathrm{~K}-\mathrm{Ar}(?)$ & Andesite & n.a. & n.a. & n.a. & n.a. & Sierra de Flores Formation lava & Pesce (1987) \\
\hline
\end{tabular}

TABLE 2. FISSION-TRACK AGES

\begin{tabular}{|c|c|c|c|c|c|c|c|c|c|c|c|c|}
\hline \multirow{3}{*}{$\begin{array}{l}\text { Isotopic age } \\
(\mathrm{Ma})\end{array}$} & \multirow[t]{3}{*}{ Mineral } & \multirow[t]{3}{*}{ Rock } & \multicolumn{9}{|c|}{ Test of fission-track data } & \multirow[t]{3}{*}{ Location } \\
\hline & & & & \multicolumn{2}{|c|}{ Spontaneous tracks } & \multicolumn{2}{|c|}{ Induced tracks } & \multirow{2}{*}{$\begin{array}{c}\text { Coefficient of } \\
\text { variation of } \\
\text { measured area }\end{array}$} & \multirow{2}{*}{$\begin{array}{l}\text { Relative } \\
\text { standard } \\
\text { deviation }\end{array}$} & \multicolumn{2}{|c|}{$\mathrm{F}$ test } & \\
\hline & & & & Average & $\begin{array}{c}\text { Coefficient of } \\
\text { variation }\end{array}$ & Average & $\begin{array}{l}\text { Coefficient } \\
\text { of variation }\end{array}$ & & & F value & $\begin{array}{c}\mathrm{nLF(0.05)} \\
\mathrm{n} 2\end{array}$ & \\
\hline $0.11 \pm 0.02$ & Zircon & Perlite & 24 & 0.7 & 1.053 & 332.3 & 0.191 & 0.069 & 0.024 & 1.38 & 2.01 & Dome \\
\hline \multirow{2}{*}{$0.29 \pm 0.07$} & Zircon & Perlite & (1) 23 & 1.5 & 1.267 & 203.3 & 0.334 & 0.257 & 0.278 & 2.08 & 2.05 & (Mt. Domo) \\
\hline & & & (2) 21 & 1.0 & 1.023 & 199.8 & 0.362 & 0.248 & 0.242 & 1.03 & 2.12 & \\
\hline $0.55 \pm 0.10$ & Zircon & Perlite & 23 & 2.0 & 0.839 & 204.3 & 0.248 & 0.133 & 0.189 & 1.27 & 2.05 & $\begin{array}{c}\text { Dome } \\
\text { (Mt. Covunco) }\end{array}$ \\
\hline
\end{tabular}




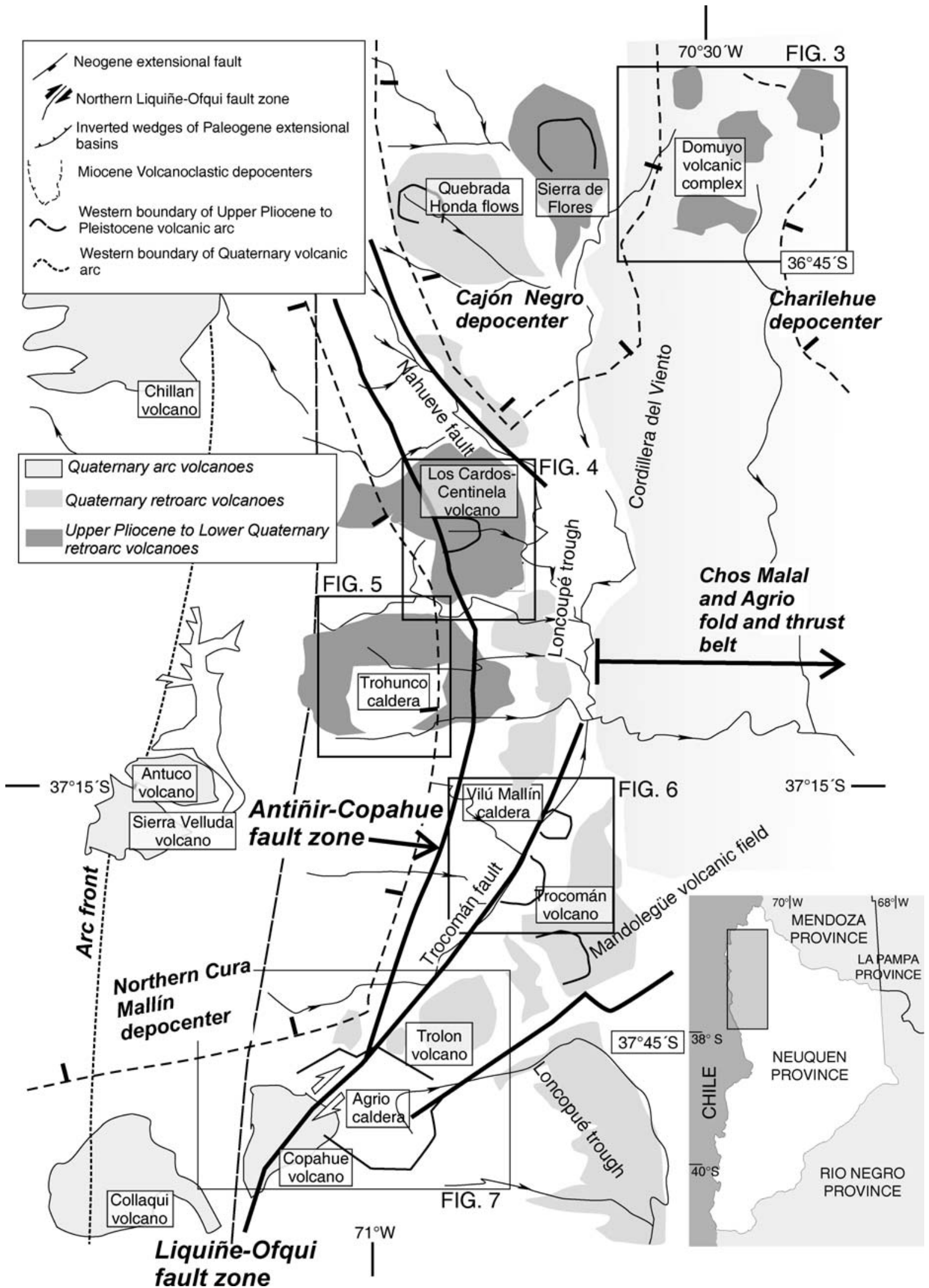

Figure 1. Map of part of the south-central Andes showing the late Quaternary Southern volcanic zone active front represented by the Chillán, Antuco, and Callaqui volcanic centers and the Upper Pliocene to Lower Pleistocene centers in the modern retroarc in Neuquén Province in Argentina. Note the general coincidence between the retroarc centers and the main fault systems known in the region. 
the frontal parts of the outer (eastern) part of the Neuquén foldand-thrust belt (Ramos and Barbieri, 1989).

At these latitudes, a series of volcaniclastic sequences has been associated with depocenters on both sides of the Neuquén Andes (Fig. 2). The youngest depocenter, entirely on the western side of the Andes and with limited exposures along the axial part of the cordillera, was generated between 15 and $10 \mathrm{Ma}$ in the southern Cura Mallín basin (Suárez and Emparán, 1995, 1997). Rocks with similar ages occur on the eastern side of the Andes. Among these are volcaniclastic sequences in the Cajón Negro Formation (Pesce, 1981, 1987), which are associated with a depocenter bounded on the south by the Nahueve fault (Fig. 1). Radiometric ages indicate an age range from 14 to $10 \mathrm{Ma}$ for the Cajón Negro Formation (Pesce, 1987). This range could be extended to 9 Ma based on an age reported by Burns (2002) east of the study area (Table 1). An equivalent unit, the Charilehue Formation (Uliana et al., 1973) extends into the Chos Malal fold-and-thrust belt (Fig. 1).

Younger volcanic units, represented by the Cola de Zorro (Niemeyer and Muñoz, 1983) and Malleco Formations (Suárez and Emparán, 1997), are widely distributed along the axial part of the Andes. Their ages are between 6 and 3.5 Ma (Niemeyer and Muñoz, 1983; Muñoz and Stern, 1988; Muñoz Bravo et al., 1989; Linares et al., 1999). These volcanic rocks appear to have largely erupted from fissures, as only a few volcanic centers of this age have been identified (see Lara and Folguera, this vol-

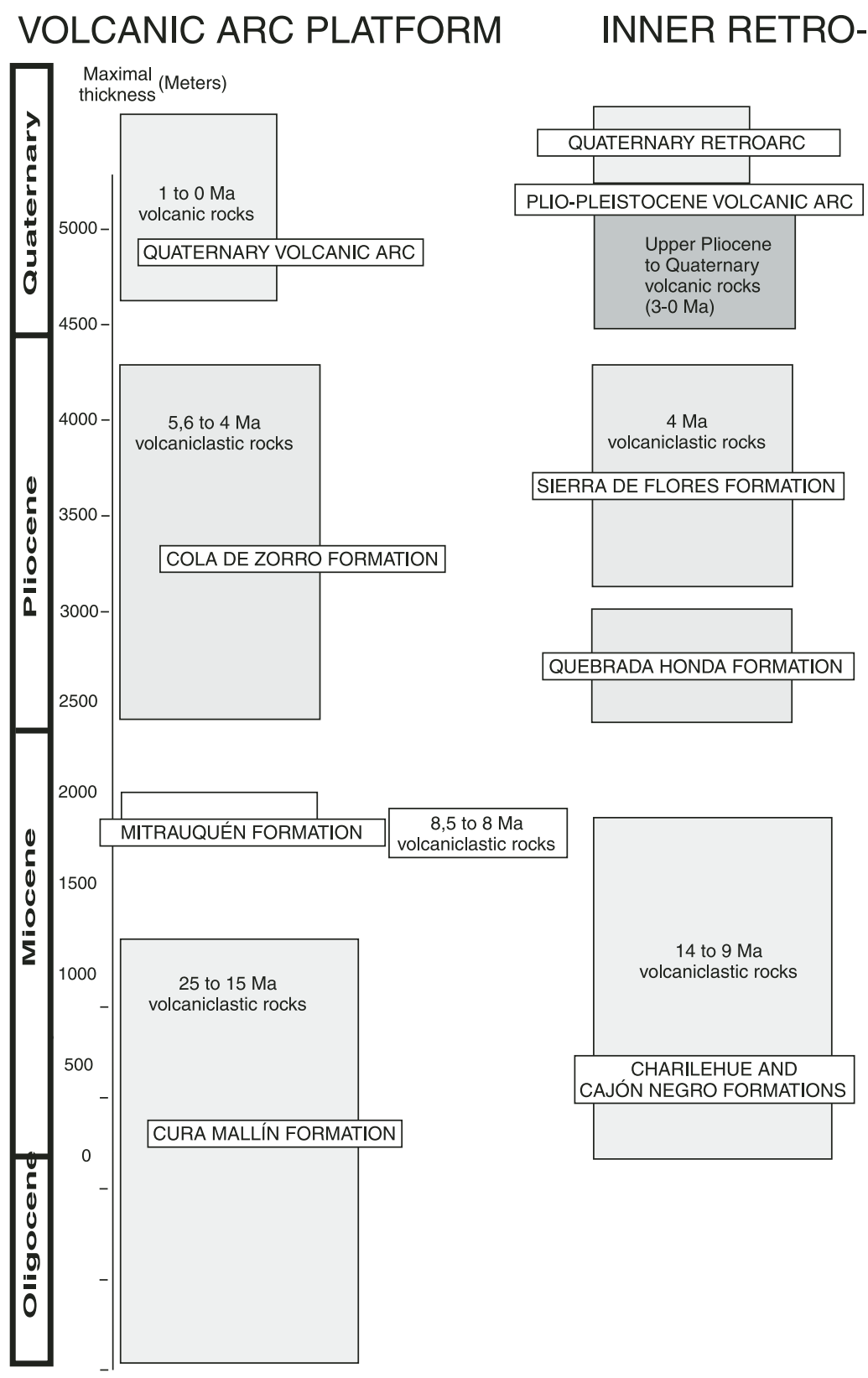

Figure 2. Stratigraphic chart showing the Neogene volcanic units in the arc and the retroarc that are discussed in the text. 
ume, chapter 14). One of these centers is the prominent Sierra de Flores volcanic center (Pesce, 1987) in the study area (Fig. 1).

The youngest centers in the region are the Upper Pliocene to Quaternary volcanic complexes described herein, which are distributed along the eastern slope of the Andes between $36^{\circ} 30^{\prime} \mathrm{S}$ and $38^{\circ} \mathrm{S}$ (Fig. 1). From north to south, the main centers are the Domuyo volcanic complex, the Los Cardos-Centinela stratovolcano, the Trohunco caldera, the Vilú Mallín caldera, and the Agrio caldera.

\section{UPPER PLIOCENE TO LOWER PLEISTOCENE VOLCANIC CENTERS}

\section{Cerro Domuyo Area}

The Cerro Domuyo area $\left(36^{\circ} 38^{\prime} \mathrm{S}, 70^{\circ} 26^{\prime} \mathrm{W}\right)$ includes one of the most important igneous centers of the northern Neuquén Andes (Fig. 1). This area has been studied from a regional geologic point of view by Groeber (1947), Llambías et al. (1978a, 1978b), Pesce (1981), and Brousse and Pesce (1982), and from a geothermal point of view by Jurio (1978), Palacios and Llambías (1978), JICA (1983), Pesce (1983, 1987), and Panarello et al. (1990).
Cerro Domuyo (4709 m) (Fig. 3) itself is a dome that is unconformably emplaced in an anticline. The anticline (Groeber, 1947) folds Permian-Triassic deposits of the Choiyoi Group and Upper Triassic to Upper Cretaceous sedimentary rocks of the Neuquén Basin (Fig. 2). The dome in the summit area of Cerro Domuyo is composed of high-K rhyolite with a porphyric and granophyric texture (Miranda, 1996). Llambías et al. (1978a, 1978b) postulated a late Miocene age for this dome based on stratigraphic considerations. The new K-Ar age of $2.5 \pm$ $0.5 \mathrm{Ma}$ in Table 1 shows that the Domuyo dome is actually late Pliocene in age (Miranda, 1996).

Other Cenozoic rocks in the Cerro Domuyo area are mainly volcanic in origin (Llambías et al., 1978b; Brousse and Pesce, 1982; Pesce, 1987). The oldest sequences are in the Charilehue Formation (Fig. 2), which is composed of basaltic andesitic to andesitic flows (Uliana et al., 1973; Llambías et al., 1978b). These flows are folded into an anticline enclosing the Domuyo intrusive dome. Everywhere, the Charilehue volcanic rocks rest in angular unconformity on folded Mesozoic sedimentary rocks (Llambías et al., 1978b). Pesce (1981) correlated the Charilehue Formation with the Cajón Negro Formation to the west (Fig. 1), the age of which is constrained by K-Ar ages of $14 \pm 2 \mathrm{Ma}$ and $10 \pm 1 \mathrm{Ma}$. The Cajón Negro Formation

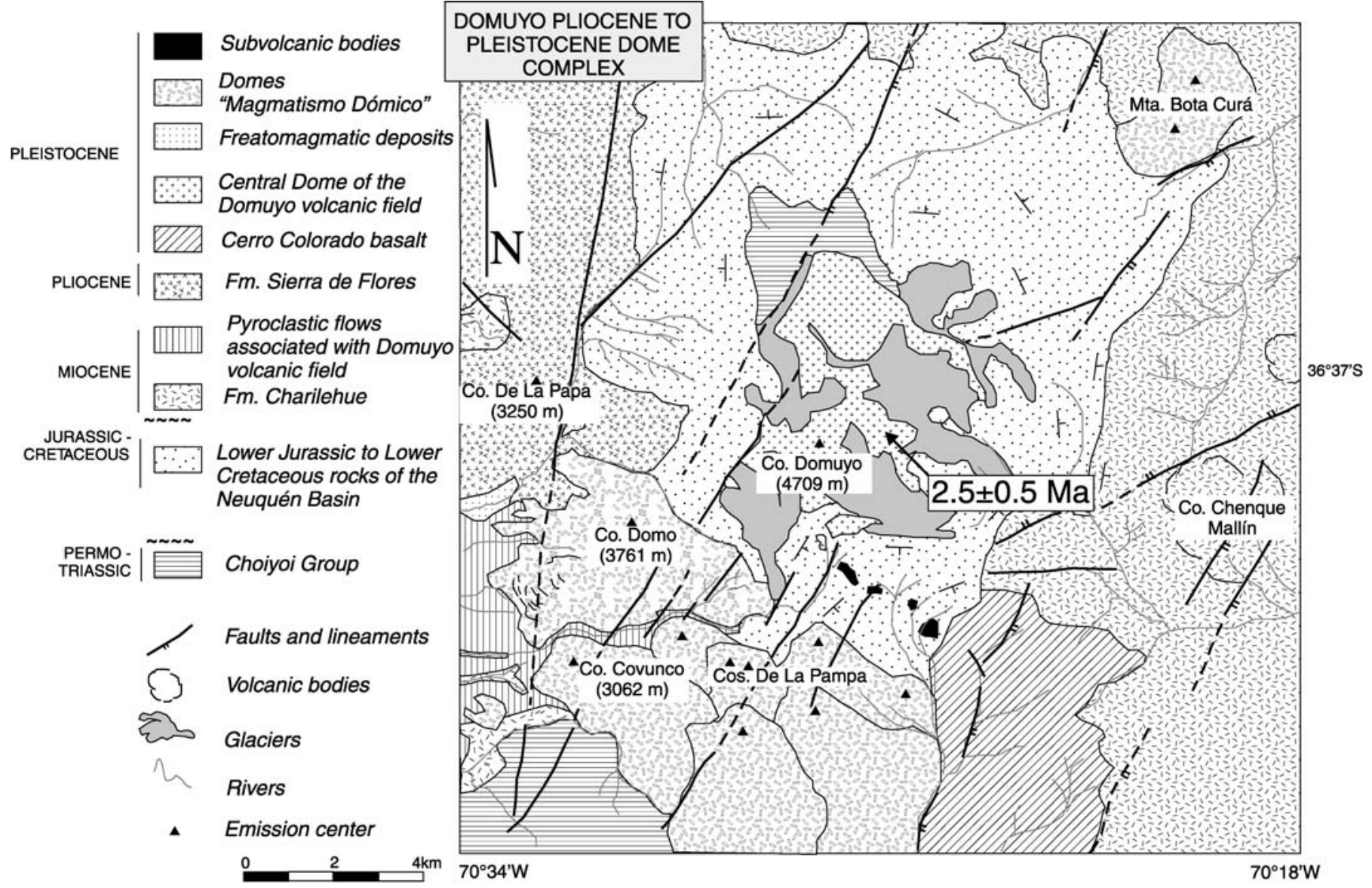

Figure 3. Map of the Domuyo volcanic complex and surrounding region showing the distribution of Permian-Triassic to Pleistocene volcanic rocks and the principal structures in the region. The arrow points to the location of the new K-Ar age in Table 1. 
extends to the international border where the sequence is gently folded. The age of the Cajón Negro Formation is further constrained by the overlying andesitic lava flows of the middle to late Miocene Quebrada Honda Formation (Pesce, 1981) and the ${ }^{40} \mathrm{Ar} /{ }^{39} \mathrm{Ar}$ age of $9 \mathrm{Ma}$ on a flow in the Nahueve valley (Burns, 2002; Burns et al., this volume, chapter 8).

Horizontally and unconformably overlaying the Charilehue Formation are the lavas flows of the Sierra de Flores Formation (Brousse and Pesce, 1982). These 1.5-2-m-thick basaltic andesitic and andesitic flows were erupted from a volcanic center west of Cerro Domuyo (Fig. 1). Their age is constrained by a $\mathrm{K}$-Ar age of $4 \pm 1.0 \mathrm{Ma}$ (Pesce, 1987).

Late Pliocene to Pleistocene volcanic activity in the Domuyo region is characterized by the phreatomagmatic rhyolitic deposits and extrusive domes that occur southwest and on the northeastern flanks of the Domuyo summit (Fig. 3). These domes, which were called the Magmatismo Dómico by Brousse and Pesce (1982), were emplaced along NE- and E-W-oriented extensional faults (Pesce, 1987). Their ages are constrained by $\mathrm{K}-\mathrm{Ar}$ ages, which range from 720 to $110 \mathrm{ka}$ (Table 1), and Pleistocene fission-track analyses on zircons, which are listed in Table 2 (Brousse and Pesce, 1982; JICA, 1983).

Llambías et al. (1978b) inferred two stages of development for the Domuyo anticline. The first involved folding of the sedimentary rocks and was considered to have occurred near the end of the Cretaceous. A second, milder phase of deformation was inferred to follow erosion of the Cretaceous sequences, postdate deposition of the Miocene Charilehue Formation, and to predate the intrusion of the Domuyo dome. There is still some uncertainty as to whether the second deformation phase is solely related to the viscous emplacement of the Domuyo dome. If the folding is regional, the deformation fits with a pulse of Neogene contractional deformation during the 14-10 Ma age assigned to the Charilehue lavas and eruption of the Sierra de Flores flows at $4 \pm 1.0 \mathrm{Ma}$. Support for regional deformation near this time comes from a $12 \mathrm{Ma}$ fission-track age for uplift in Burns (2002) on the eastern slope of the Cordillera del Viento, immediately south of the Domuyo area. Other support comes from the argument of Kay et al. (this volume, chapter 2) that compressional deformation occurred between $11 \pm 0.2 \mathrm{Ma}$ and $4.0 \pm 0.4 \mathrm{Ma}$ just east of the Cordillera del Viento. A further constraint on the youngest age of deformation comes from the Pleistocene domes of the Domuyo complex.

\section{Los Cardos-Centinela Volcanic Center}

To the south of the Domuyo center is the Los CardosCentinela volcanic center $\left(37^{\circ} 06^{\prime} \mathrm{S}, 70^{\circ} 52^{\prime} \mathrm{W}\right)$ (Figs. 1 and 4$)$. The main edifice is a stratovolcano that erupted olivine and plagioclase-bearing basalts and subordinate pyroclastic deposits. The age of this center has been constrained between 3.2 and $2.5 \mathrm{Ma}$ (Rovere, 1993, 1998). The eastern face of the stratovolcano shows minimal erosion, whereas the western slope has been heavily affected by Holocene mass wasting (González Díaz et al., 2005). The top of the center contains a summit caldera that has a poorly constrained age. Postdating the caldera is a series of minor preglacial stratovolcanoes that erupted near the apex. Moderate amounts of postcaldera dome activity also occurred on the eastern flank (Fig. 4). Based on the pillow-like structures in the youngest flows, the latest volcanic activity is considered to have occurred during synglacial times. In analogy with the glacial history of the Chillán volcano (Dixon et al., 1999) to the west (Fig. 1), the latest volcanic activity would have occurred after $30 \mathrm{ka}$.

A Miocene age for the principal deformation in this region can be inferred from the fact that the 3.2-2.5 Ma lavas of the Los Cardos-Centinela stratovolcano, along with underlying early Pliocene Cola de Zorro volcanic rocks, lie in angular unconformity over deformed strata of the Miocene Cura Mallín Formation. The youngest age of deformation is constrained by deformed avalanche deposits west of the center. The age of these deposits is considered to be younger than $30 \mathrm{ka}$, based on the absence of glacial erosive features on the avalanche deposits. Folding and reverse faulting in these deposits show a N to NW trend (Folguera et al., this volume, chapter 11).

\section{Trohunco Caldera Area}

Farther south is the partially eroded Trohunco caldera $\left(37^{\circ} 18^{\prime} \mathrm{S}, 71^{\circ} 01^{\prime} \mathrm{W}\right)$, which is located on the eastern side of the Andes, west of the Loncopué trough (Fig. 1). Volcanic rocks from this center are largely andesitic breccias that have porphyritic textures and contain vesicles up to $8 \mathrm{~mm}$ in diameter. The phenocrysts, which make up $45 \%$ of the rock, are mainly plagioclase (40\%), augite (5\%), and accessory small opaque minerals.

This $15-\mathrm{km}$-diameter caldera is comparable to the similarsized Agrio caldera farther south (Fig. 1) in that its rim (precaldera units) is formed by Lower Pliocene volcanic rocks of the Cola de Zorro Formation. It differs in not having a resurgent facies. However, these facies could have been removed, since the eastern half of the caldera has been eroded at the orogenic front (Fig. 5). Volcanic rocks outside of the caldera have yielded K-Ar ages of $3.6 \pm 0.2$ and $3.6 \pm 0.5 \mathrm{Ma}$ (Muñoz Bravo et al., 1989).

The relationship between this volcanic center and surrounding volcanic units shows that two main pulses of contractional deformation occurred in the area. The oldest one is indicated by an angular unconformity that separates folded sequences of early Miocene age from subhorizontal lava flows dated at 3.6 Ma. A younger contractional deformation is indicated by Pliocene intracaldera volcanic rocks near the eastern edge of the caldera that are affected by gentle folding. These rocks are in turn overridden by Lower Miocene volcanic rocks in a NW-oriented high-angle reverse fault (Fig. 5). This deformation appears to be associated with a system of N-NW-trending faults and folds that Folguera et al. (this volume, chapter 11) consider to be Quaternary in age

\section{Vilú Mallín Caldera Area}

The 6-7-km-diameter Vilú Mallín caldera $\left(37^{\circ} 28^{\prime} \mathrm{S}\right.$, $70^{\circ} 45^{\prime} \mathrm{W}$ ) (Fig. 6) is located in the northern part of the Quaternary Loncopue trough to the east of the Trohunco, Los Cardos- 


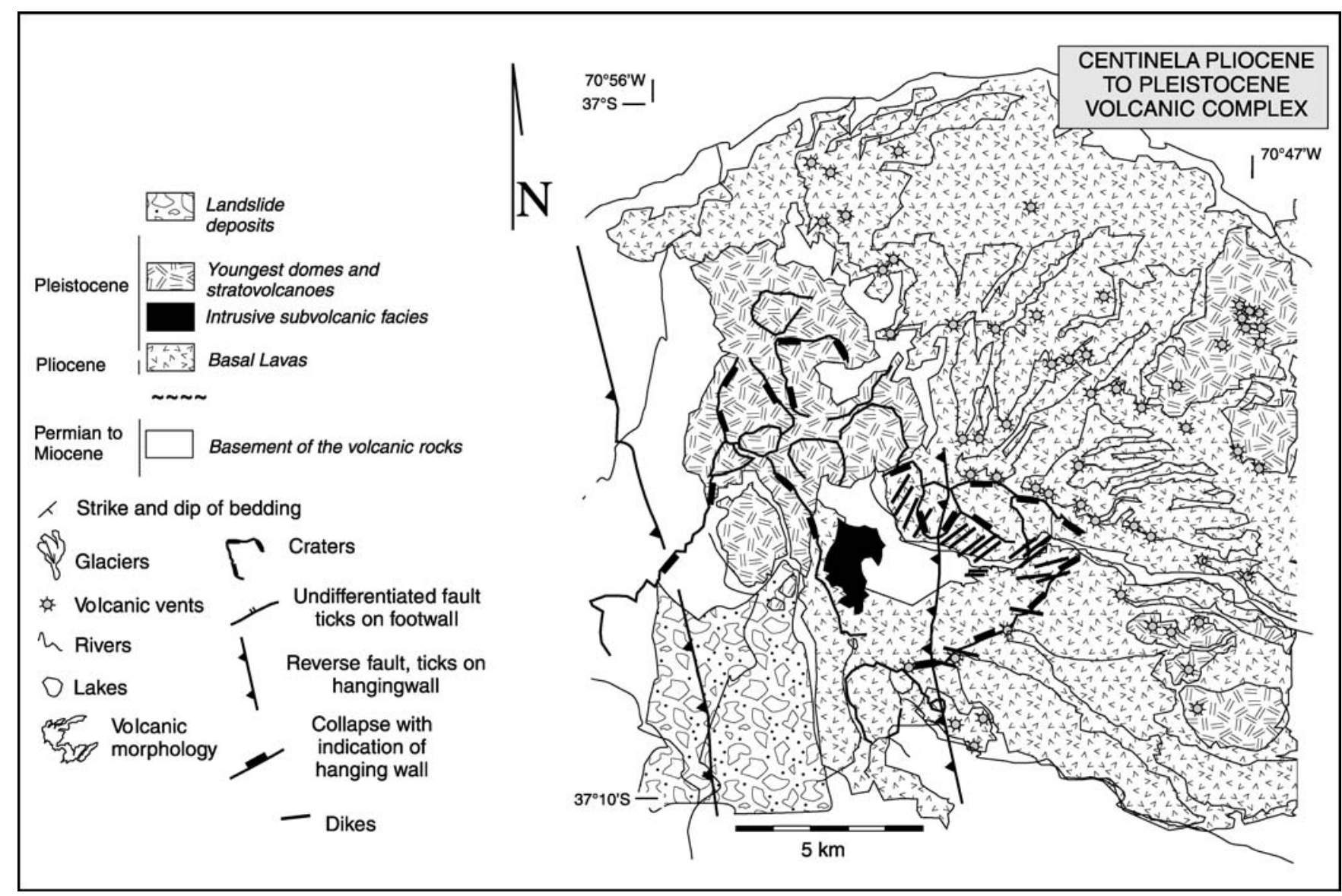

Figure 4. Map of the Pliocene to Pleistocene Centinela volcanic complex showing the distribution of volcanic and subvolcanic units relative to reverse faults and caldera collapse.

Centinela, and Agrio calderas (Fig. 1). The principal volcanic rocks are basaltic andesites, which have plagioclase and augite phenocrysts that compose $20 \%$ of the rock. The caldera was formed by the collapse of a plateau made up of a precaldera sequence that has yielded a K-Ar age of $4 \pm 0.5 \mathrm{Ma}$ (Table 1). The southern part of the depression has been obliterated by postcaldera monogenetic pulses of basic lavas, one of which yielded a K-Ar age of 3.1 $\pm 0.2 \mathrm{Ma}$ (Table 1). Resurgent activity has also formed a series of basaltic domes that erupted from annular rings around the edge of the caldera.

The Vilú Mallín volcanic center, the Mandolegüe volcanic field, and Trocomán volcano, are aligned in a NE-trending volcanic chain that is controlled by the Trocomán dextraltranstensional fault (Figs. 1 and 6). An apparent displacement in the Vilú Mallín caldera rim (Fig. 6) suggests probable activity on this fault during the last $4 \mathrm{~m}$.y. The volcanic basement of these three complexes is an andesitic plateau, which has yielded a K-Ar age of $6.8 \pm 0.4 \mathrm{Ma}$ (Table 1). This volcanic basement horizontally covers folded strata of Lower Miocene age.

Observations from the Vilú Mallín center and the underlying $6.8 \pm 0.4 \mathrm{Ma}$ andesitic plateau help to constrain the age of Neogene deformation in the area. A first observation is that the basal lavas of the Vilú Mallín center erupted over a regional angular unconformity on sedimentary beds of the Lower Miocene Cura Mallín Formation in the Reñileuvú valley (Fig. 6). A second is that the Vilú Mallín center is cut by the Trocomán valley (Fig. 6), which is the morphological expression of the NE-trending Trocomán fault. This fault system includes a series of along-strike pull-apart basins that formed in response to dextral displacement (Folguera et al., 2004). The basal volcanic rocks of the Vilú Mallín caldera occur in a small pull-apart basin formed directly along the Trocomán fault trace (Figs. 1 and 6). Despite evidence for strike-slip motion, the main effect of the Trocomán fault is the extensional faulting that led to the collapse of the southern side of the caldera (Fig. 6).

\section{The Agrio Caldera}

The Agrio caldera $\left(37^{\circ} 51^{\prime} \mathrm{S}, 70^{\circ} 26^{\prime} \mathrm{W}\right.$ ) (Figs. 1 and 7) is a quadrangular $(15 \times 20 \mathrm{~km})$ depression filled by volcaniclastic successions with ages ranging from $2.5 \mathrm{Ma}$ to younger than 30 ka (Pesce, 1989; Linares et al., 1999; Melnick and Folguera, 2001). The volcanic rocks vary from andesitic to basaltic in composition. Most have porphyritic texture and typically contain 25\% plagioclase and 5\% augite phenocrysts. Aphanitic textures are also present. 


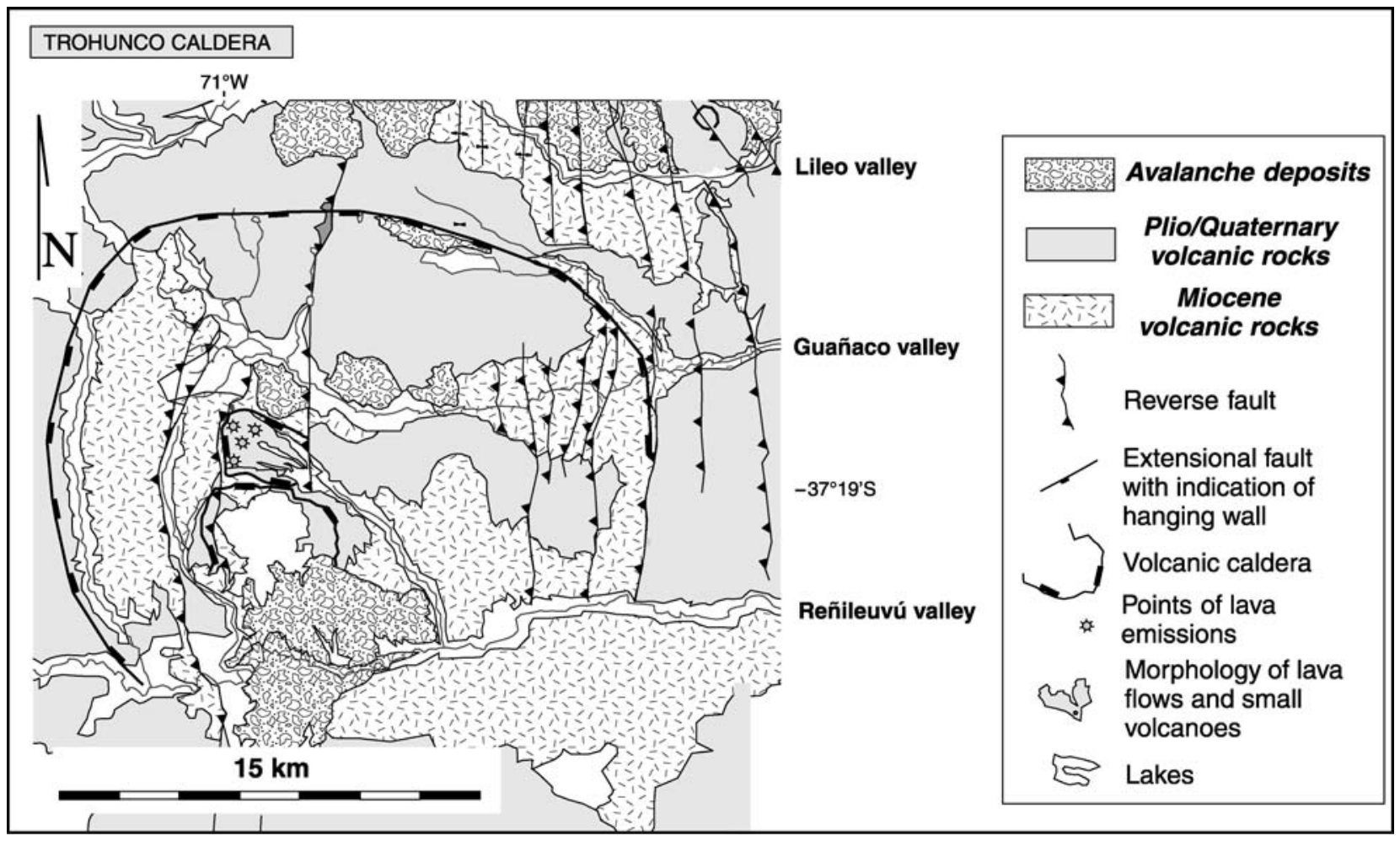

Figure 5. Map of the Pliocene to Pleistocene Trohunco caldera showing the crater relative to the distribution of Miocene and Pliocene-Quaternary volcanic rocks and avalanche deposits in the region and the reverse faults that cut them.

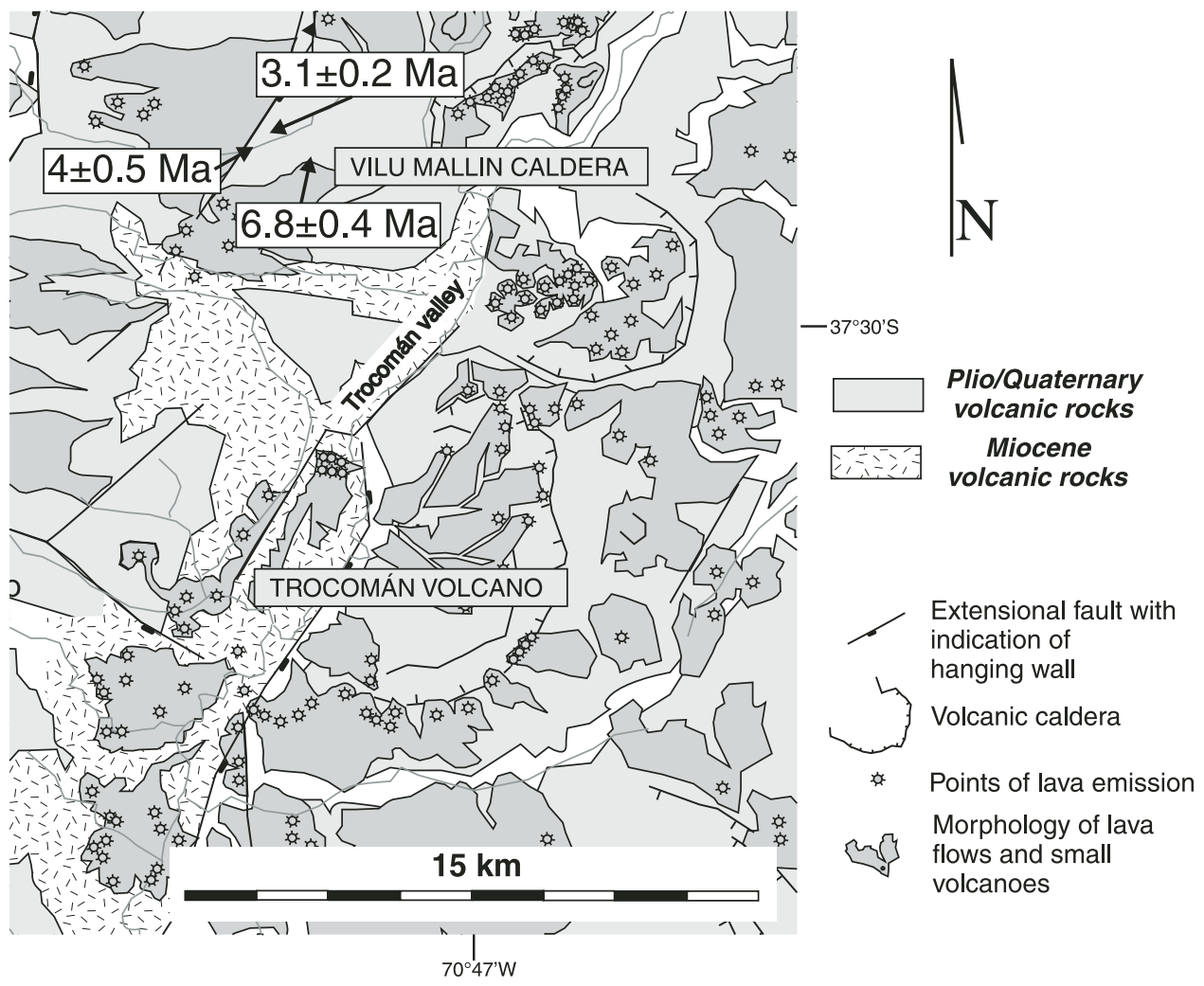

Figure 6. Map showing the distribution of Miocene and Pliocene-Quaternary volcanic units in the region of the Vilú Mallín caldera and Trocomán volcanic complex and the extensional faults that cut them. The arrows point to the locations of the new K-Ar ages in Table 1. 
The collapse that created the Agrio caldera took place in more than one episode (Melnick and Folguera, 2001). The oldest syncaldera volcanic rocks that are associated with the earliest collapse are part of the Las Mellizas Formation (Pesce, 1989). The Las Mellizas Formation, which has been dated at $2.5 \mathrm{Ma}$ (Pesce, 1989), covers most of the caldera. Its main depocenter is near the northwestern half of the volcanic depression (Fig. 7). The age of the second collapse is bracketed between 1.6 and $0.8 \mathrm{Ma}$ (Pesce, 1989). This collapse is restricted to the northern part of the caldera, where it occurred along a W- to NW-trending extensional fault system (Folguera and Ramos, 2000). Similarly oriented extensional fault systems in the southern part of the caldera have controlled the emplacement of volcanic rocks with ages from 1.2 Ma to synglacial. The 1.2 Ma age corresponds to the basal lavas of the Copahue volcano, which fill two extensional depocenters. One center is in the western part of El Agrio graben, and the other is a small pull-apart basin along the upper Lomín River (Melnick and Folguera, 2001). Synglacial volcanic rocks, the ages of which have been inferred from pillowlike structures related to flow under the ice, are systematically controlled by W- to NW-trending structures (Melnick et al., this volume, chapter 4). Postglacial volcanic rocks in the Copahue volcano and to the north (Fig. 7) are controlled by NE-trending extensional faults (Folguera and Ramos, 2000).

The Agrio caldera shows the relations between several pulses of deformation, which can also be seen in neighboring volcanic centers. The youngest precaldera sequences in the area have ages of 5-4 Ma (Linares et al., 1999) and belong to the Cola de Zorro Formation (Niemeyer and Muñoz, 1983). These rocks unconformably cover the Lower Miocene Cura Mallín
Formation, indicating a widespread pulse of post-early Miocene compressive deformation. The Agrio caldera is a transtensional basin that is controlled by W-NW- and NE-trending normal faults (Fig. 7). These faults form an almost rhombohedral depocenter that is internally segmented by W-NW-trending faults. Well-dated synextensional volcanic rocks indicate recurrent collapse in the area.

The caldera and other transtensional depocenters in the region were active in the late Pliocene after the Cola de Zorro eruptions, and continued to be active through the Quaternary until postglacial times. The main regional structures controlling the collapse of the Agrio caldera area can be seen in Figure 1. These are: (1) the northernmost end of the Liquiñe-Ofqui fault zone, which runs through the Upper Pleistocene to Holocene volcanic front to the south (Lavenu and Cembrano, 1999), and (2) the southern end of the Antiñir-Copahue fault system, which runs through the inner retroarc zone (Folguera et al., 2004). Both fault systems have a dextral component associated with differing amounts of extension and compression as the faults change orientation. The clockwise step design of these two fault-system traces is compatible with the development of transtension in the Agrio caldera area (Fig. 7).

\section{DISCUSSION AND CONCLUSIONS}

Fission-track ages of 12 Ma (Burns, 2002) from the Cordillera del Viento, immediately to the south of Cerro Domuyo (Fig. 1), show that the youngest major uplift in the region occurred in the late Miocene. Based on geochronological data and field relationships between the Domuyo igneous complex and its basement, two pulses of deformation can be identified in
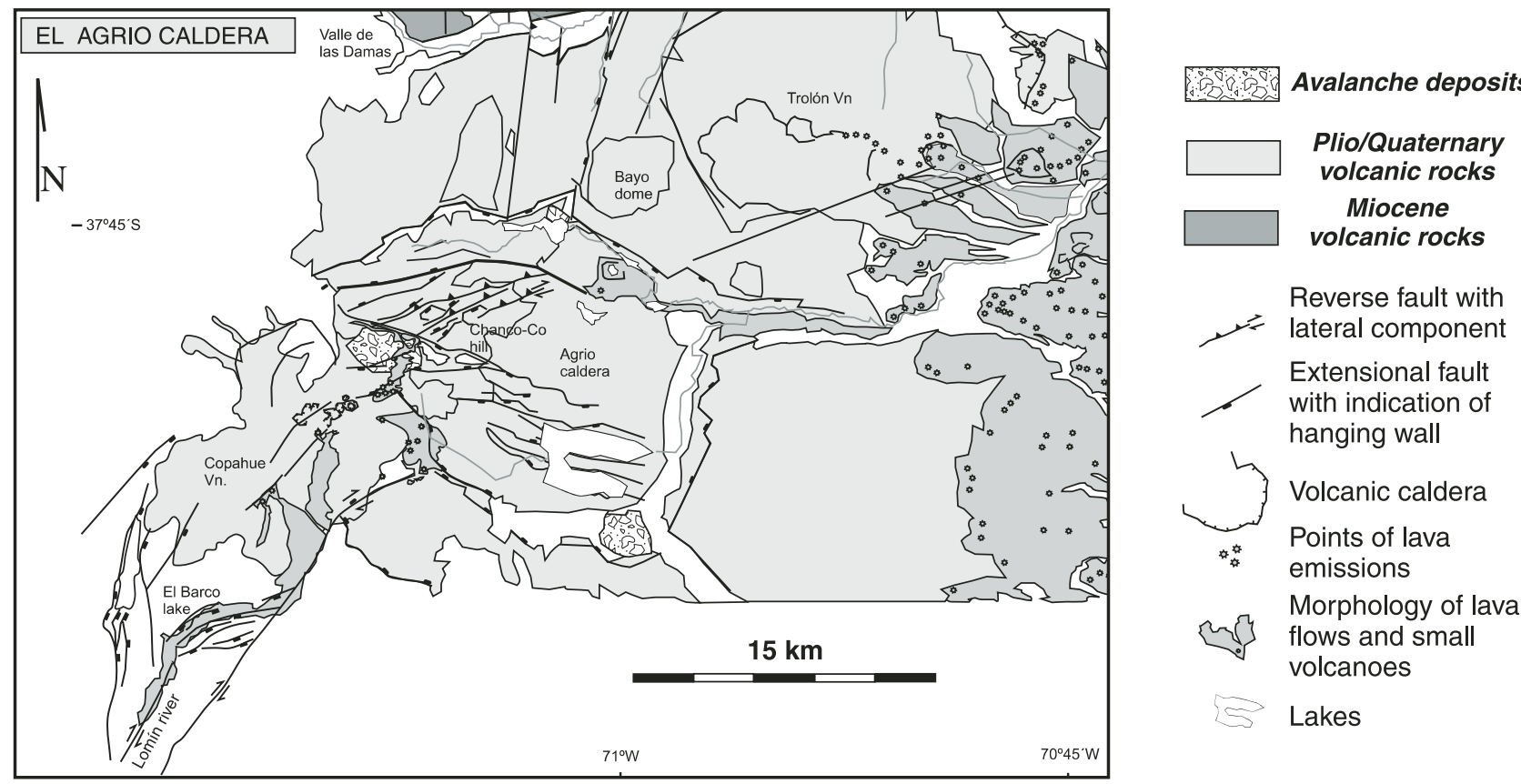

Reverse fault with $=$ lateral component Extensional fault with indication of hanging wall

Volcanic caldera

Points of lava emissions Morphology of lava flows and small volcanoes

Lakes

Figure 7. Map of the El Agrio caldera region showing the distribution of Miocene and Pliocene-Quaternary volcanic rocks relative to avalanche deposits and the major structures in the region. See text for discussion. 


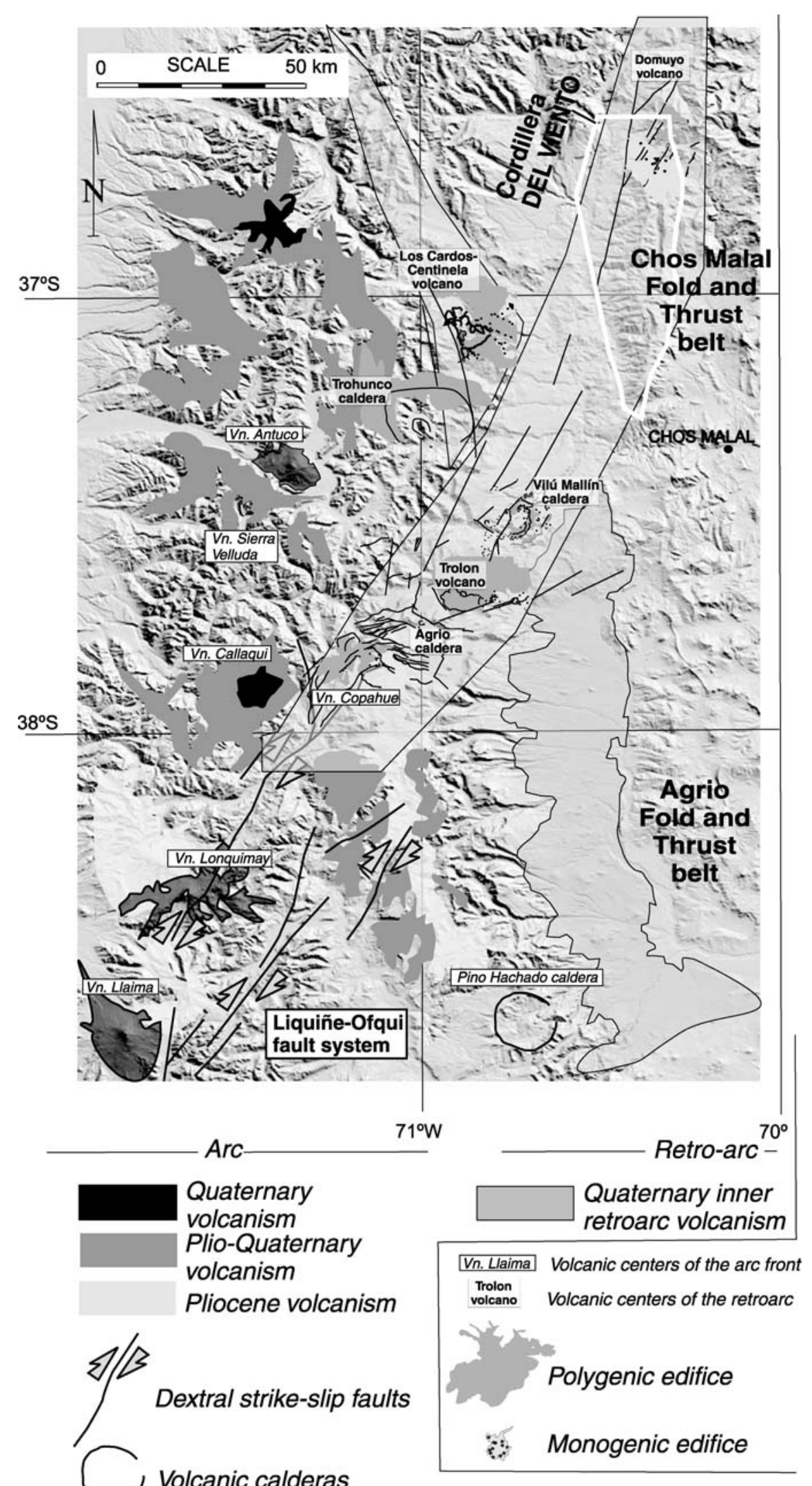

Figure 8. Regional map showing the interplay of Pliocene-Quaternary extensional and contractional deformational systems in the retroarc. The Los Cardos-Centinela and Trohunco centers occur in the region where contraction has occurred along N-NW-oriented faults. Cerro Domuyo, Vilú Mallín, and the Agrio caldera occur in the region where extension has occurred along NE-trending fault systems. See text for further discussion. 
the last 15 m.y. that appear to be of regional extent. The first produced the folding in the Charilehue Formation after 10-9 Ma, and the second, the extension and the collapse of the northern part of the Cordillera del Viento after $1 \mathrm{Ma}$.

The first pulse that folded the Charilehue Formation must be younger than 10-9 Ma if the age correlation with the Cajón Negro Formation is correct. This pulse is either younger than the 12 Ma uplift proposed by Burns (2002), or the fissiontrack age does not accurately reflect the last uplift, or the folding of the Charilehue Formation was not associated with substantial uplift. Based on field relations with the $4 \mathrm{Ma}$ Sierra de Flores Formation lavas that horizontally cover and unconformable overlie middle Miocene lava flows, the pulse that folded the Charilehue Formation can be constrained between 9 and 4 Ma. The analysis of the Vilú Mallín and Agrio calderas (Figs. 6, 7, and 8) puts other constraints on the age of contractional deformation in the region. Constraints on the upper age of deformation at these centers are $6.8 \mathrm{Ma}$ and $5 \mathrm{Ma}$, respectively. Taken together with the constraints in the Domuyo region, regional-scale contraction likely occurred between 9 and $6.8 \mathrm{Ma}$.

The second pulse of deformation involved extension and collapse. This pulse is shown in the Domuyo area by the emplacement of the Pleistocene domes that were favored by extensional structures. Extensional deformation is also recorded in the Vilú Mallín and Agrio caldera areas, where NE-trending extensional fault systems were active during late Pliocene to Quaternary times (Fig. 8).

In contrast, the Los Cardos-Centinela volcanic complex and Trohunco caldera show a different style for the youngest deformational pulse. In the Los Cardos-Centinela center, N-NWtrending structures indicate contraction during the late Quaternary. At the Trohunco caldera, the N-NW-trending system shows evidence for contractional deformation in the late Pliocene to Quaternary.

Based on these differences, the volcanic centers can be put in two groups. The first includes the Agrio and Vilú Mallín calderas and the Domuyo volcanic complex, and the second the Centinela and Trohunco centers. The first group erupted in relation to NE-trending Pliocene to Quaternary extensional fault systems (Figs. 6, 7, and 8), and the second is associated with NW-trending contractional faults active in Quaternary times. On a regional scale, this difference reflects the inhomogeneous nature of young deformation in the area and the strain partitioning between faults, which accommodates extension and contraction at the same time.

\section{ACKNOWLEDGMENTS}

The authors would like to thank Adriana Bermúdez and Eduardo Llambías for their reviews of an earlier version of this manuscript. This study was made possible by funding from PICT 06729/99 of Agencia Nacional de Promoción Científica y Tecnológica to V.A. Ramos. We thank Suzanne Mahlburg Kay for several reviews and suggestions that substantially improved the presentation and clarified the concepts in this paper.

\section{REFERENCES CITED}

Bohm, M., Lüth, S., Echtler, H., Asch, G., Bataille, K., Bruhn, C., Rietbrock, A., and Wigger, P., 2002, The Southern Andes between $36^{\circ}$ and $40^{\circ} \mathrm{S}$ latitude: Seismicity and average seismic velocities: Tectonophysics, v. 356, p. 275-289, doi: 10.1016/S0040-1951(02)00399-2.

Brousse, R., and Pesce, A.H., 1982, Cerro Domo: Un volcán Cuartario con posibilidades geotermicas. Provincia del Neuquén, in Proceedings, 5th Congreso Latinoamericano de Geología: Buenos Aires. Servicio Geológico Nacional, Subsecretaria de Minería, v. 4, p. 197-208.

Burns, W.M., 2002, Tectonics of the Southern Andes from stratigraphic, thermochronologic, and geochemical perspectives [Ph.D. thesis]: Ithaca, New York, Cornell University, 204 p.

Burns, W.M., Jordan, T.E., Copeland, P., and Kelley, S.A., this volume, The case for extensional tectonics in the Oligocene-Miocene Southern Andes as recorded in the Cura Mallín basin $\left(36^{\circ}-38^{\circ} \mathrm{S}\right)$, in Kay, S.M., and Ramos, V.A., eds., Evolution of an Andean margin: A tectonic and magmatic view from the Andes to the Neuquén Basin $\left(35^{\circ}-39^{\circ} \mathrm{S}\right.$ lat): Geological Society of America Special Paper 407, doi: 10.1130/ 2006.2407(08).

Dixon, H., Murphy, M., Sparks, S., Chávez, R., Naranjo, J., Dinkley, P., Young, S., Gilbert, J., and Pringle, M., 1999, The geology of Nevados de Chillán volcano, Chile: Revista Geológica de Chile, v. 26, no. 2, p. 227-253.

Folguera, A., and Ramos, V.A., 2000, Control estructural del volcán Copahue: Implicancias tectónicas para el arco volcánico Cuaternario $\left(36^{\circ}-39^{\circ} \mathrm{S}\right)$ : Revista de la Asociación Geológica Argentina, v. 55, p. 229-244.

Folguera, A., Ramos, V.A., Hermanns, R., and Naranjo, J., 2004, Neotectonics in the foothills of the southernmost central Andes $\left(37^{\circ}-38^{\circ} \mathrm{S}\right)$ : Evidence of strike-slip displacement along the Antiñir-Copahue fault zone: Tectonics, v. 23, TC5008, doi: 10.1029/2003TC011533.

Folguera, A., Ramos, V.A., González Díaz, E.F., and Hermanns, R., 2006, this volume, Miocene to Quaternary deformation of the Guañacos fold-andthrust belt in the Neuquén Andes between $37^{\circ} \mathrm{S}$ and $37^{\circ} 30^{\prime} \mathrm{S}$, in Kay, S.M., and Ramos, V.A., eds., Evolution of an Andean margin: A tectonic and magmatic view from the Andes to the Neuquén Basin $\left(35^{\circ}-39^{\circ} \mathrm{S}\right.$ lat): Geological Society of America Special Paper 407, doi: 10.1130 /2006.2407(11)

González Díaz, E., 2005, Geomorfología de la región del volcán Copahue y sus adyacencias (centro-oeste del Neuquén, Argentina): Revista de la Asociación Geológica Argentina, v. 60, no. 1, p. 72-87.

Groeber, P., 1947, Observaciones geológicas a lo largo del meridiano 70.3, hojas Domuyo, Mari Mahuida, Huarhuar Co y parte de Epu Lauken Revista Sociedad Geologica Argentina, v. 2, no. 4, p. 347-408, 3 sheets.

JICA (Japan International Cooperation Agency), 1983, Interim report on the northern Neuquén geothermal development project: Tokyo, Japan International Cooperation Agency Open-File Report.

Jurio, R.L., 1978, Algunos aspectos geotermicos de las manifestaciones hidrotermales del Cerro Domuyo. Provincia del Neuquén. Argentina: Revista Minería, v. 179, p. 45-52.

Kay, S.M., Burns, W.M., Copeland, P., and Mancilla, O., 2006, this volume, Upper Cretaceous to Holocene magmatism and evidence for transient Miocene shallowing of the Andean subduction zone under the northern Neuquén Basin, in Kay, S.M., and Ramos, V.A., eds., Evolution of an Andean margin: A tectonic and magmatic view from the Andes to the Neuquén Basin $\left(35^{\circ}-39^{\circ} \mathrm{S}\right.$ lat): Geological Society of America Special Paper 407, doi: 10.1130/2006.2407(02).

Lara, L., Rodríguez, C., Moreno, H., and Pérez de Arce, H., 2001, Geocronología K-Ar y geoquímica del volcanismo Plioceno superiorPleistoceno de los Andes del sur $\left(39^{\circ}-42^{\circ} \mathrm{S}\right)$ : Revista Geológica de Chile, v. 28, no. 1, p. 67-90

Lara, L.E., and Folguera, A., 2006, this volume, The Pliocene to Quaternary narrowing of the Southern Andean volcanic arc between $37^{\circ}$ and $41^{\circ} \mathrm{S}$ latitude, in Kay, S.M., and Ramos, V.A., eds., Evolution of an Andean margin: A tectonic and magmatic view from the Andes to the Neuquén Basin ( $35^{\circ}-39^{\circ} \mathrm{S}$ lat): Geological Society of America Special Paper 407 , doi: 10.1130/2006.2407(14). 
Lavenu, A., and Cembrano, J., 1999, Compressional and transpressional stress pattern for Pliocene and Quaternary brittle deformation in fore arc and intraarc zones (Andes of central and southern Chile): Journal of Structural Geology, v. 21, p. 1669-1691, doi: 10.1016/S0191-8141(99)00111-X.

Linares, E., Ostera, H.A., and Mas, L., 1999, Cronología potasio-argón del complejo efusivo Copahue-Caviahue, Provincia de Neuquén: Revista de la Asociación Geológica Argentina, v. 54, p. 240-247.

Llambías, E.J., Palacios, M., Danderfer, J.C., and Brogioni, N., 1978a, Petrología de las rocas ígneas Cenozoicas del Volcán Domuyo y áreas adyacentes, Provincia del Neuquén, in Proceedings, 7th Congreso Geológico Argentino: Neuquén, Asociación Geológica Argentina, v. 2, p. 553-568.

Llambías, E.J., Danderfer, J.C., Palacios, M., and Brogioni, N., 1978b, Las rocas ígneas Cenozoicas del Volcán Domuyo y áreas adyacentes, Provincia del Neuquén, in Proceedings, 7th Congreso Geológico Argentino: Neuquén, Asociación Geológica Argentina, v. 2, p. 569-584.

López-Escobar, L., Cembrano, J., and Moreno, H., 1995, Geochemistry and tectonics of the Chilean Southern Andes basaltic Quaternary volcanism $\left(37^{\circ}-46^{\circ} \mathrm{S}\right)$ : Revista Geológica de Chile, v. 22, p. 219-234.

Melnick, D., and Folguera, A., 2001, Geologia del complejo volcánico Copahue-Caldera Del Agrio, un sistema transtensional activo desde el Plioceno en la transición de los Andes Patagónicos a los Andes Centrales $\left(38^{\circ} \mathrm{S}-71^{\circ} \mathrm{O}\right)$, in Proceedings, 9th Congreso Geológico Latinoamericano, Symposium "Evolución Tectónica de los Andes": Montevideo, Uruguay, Universidad de Montevideo, p. 6-11.

Melnick, D., Rosenau, M., Folguera, A., and Echtler, H., 2006, this volume, Neogene tectonic evolution of the Neuquén Andes western flank $\left(37-39^{\circ}\right.$ S), in Kay, S.M., and Ramos, V.A., eds., Evolution of an Andean margin: A tectonic and magmatic view from the Andes to the Neuquén Basin ( $35^{\circ}-39^{\circ} \mathrm{S}$ lat): Geological Society of America Special Paper 407, doi: 10.1130/2006.2407(04).

Miranda, F.J., 1996, Caracterización petrográfica y geoquímica del Cerro Domuyo, Pcia. de Neuquén, Argentina [Licenciatura thesis]: Buenos Aires, Facultad de Ciencias Exactas y Naturales, Universidad de Buenos Aires, $118 \mathrm{p}$.

Muñoz, J., and Stern, C., 1988, The Quaternary volcanic belt of the Southern continental margin of South America: Transverse structural and petrochemical variations across the segment between $38^{\circ} \mathrm{S}$ and $39^{\circ} \mathrm{S}$ : Journal of South American Earth Sciences, v. 1, p. 147-162, doi: 10.1016/08959811(88)90032-6.

Muñoz Bravo, J., Stern, C., Bermúdez, A., Delpino, D., Dobbs, M.F., and Frey, F.A., 1989, El volcanismo Plio-Cuaternario a través de los $38^{\circ}$ y $39^{\circ} \mathrm{S}$ de los Andes: Revista de la Asociación Geológica Argentina, v. 44, p. 270-286.

Niemeyer, H., and Muñoz, J., 1983, Geología de la hoja 57 Laguna de La Laja, región de Bío Bío: Santiago, Chile, Servicio Nacional de Geología y Minería, scale 1:250,000, 1 sheet.

Palacios, M., and Llambías, E.J., 1978, Las fuentes termales del volcán Domuyo, Provincia de Neuquén, in Proceedings, 7th Congreso Geológico Argentino: Neuquén, Asociación Geológica Argentina, v. 2, p. $145-159$.

Panarello, H., Sierra, J., D’Amore, F., and Pedro, G., 1990, Isotopic and geochemical study of the Domuyo geothermal field, Neuquén Argentina, in Proceedings, Geothermal Investigations with Isotopes and Geochemical Techniques in Latin America: San José, Costa Rica, Final Research coordination meeting, 12-16 November 1990: OIEA (Organización Internacional de Energía Atómica), v. 1992, p. 31-56.

Pardo Casas, F., and Molnar, P., 1987, Relative motion of the Nazca (Farallon)-South American plates since Late Cretaceous time: Tectonics, v. 6, p. 233-248.

Pesce, A., 1981, Estratigrafía de las nacientes del Río Neuquén y Nahuever Provincia del Neuquén, in Proceedings, 8th Congreso Geológico Argentino: San Luis, Asociación Geológica Argentina, v. 3, p. 439-455.
Pesce, A.H., 1983, Evaluación geotérmica del área del cerro Domuyo (Neuquén): SEGEMAR (Servicio Geológico Minero Argentino) Argentina Open-File Report, Serie Contribuciones Técnicas, Geotermia, v. $1,46 \mathrm{p}$.

Pesce, A.H., 1987, Evaluación geotermica del area Cerro Domuyo, Provincia del Neuquén, República Argentina: Revista Brasileira de Geofísica, v. 5, p. 283-299.

Pesce, A., 1989, Evolución volcano-tectónica del complejo efusivo CopahueCaviahue y su modelo geotérmico preliminar: Revista de la Asociación Geológica Argentina, v. 44, no. 1-4, p. 307-327.

Ramos, V.A., 1977, Estructura de la Provincia de Neuquén, in Rolleri, E.O.. eds., Geología y recursos naturales de la Provincia del Neuquén: 7th Congreso Geológico Argentino (Neuquén): Buenos Aires, Asociación Geológica Argentina, p. 9-24.

Ramos, V.A., 1999, Plate tectonic setting of the Andean Cordillera: Episodes, v. 22, no. 3, p. 183-190.

Ramos, V.A., and Barbieri, M., 1989, El volcanismo Cenozoico de Huantraico: Edad y relaciones isotópicas iniciales, Provincia del Neuquén: Revista de la Asociación Geológica Argentina, v. 43, p. 210-223.

Ré, G.H., Geuna, S.E., and López Martínez, M., 2000, Geoquímica y geocronología de los basaltos de la región de Aluminé (Neuquen-Argentina), in Proceedings, 9th Congreso Geológico Chileno: Puerto Varas, Servicio Nacional de Geología y Minería de Chile, v. 2, no. 6, p. 62-66.

Rovere, E., 1993, K/Ar ages of magmatic rocks and geochemical variations of volcanics from South Andes ( $37^{\circ}$ to $\left.37^{\circ} 15^{\prime} \mathrm{S}-71^{\circ} \mathrm{W}\right)$, in Proceedings, 2nd Japan Volcanological Society: p. 107.

Rovere, E., 1998, Volcanismo Jurásico, Paleógeno y Neógeno en el noroeste del Neuquén, Argentina, in Proceedings, 10th Congreso Latinoamericano de Geología: Buenos Aires, Servicio Geológico Minero Argentino, v. 1 , p. 144-149.

Suárez, M., and Emparán, C., 1995, The stratigraphy, geochronology and paleophysiography of a Miocene fresh-water interarc basin, southern Chile: Journal of South American Earth Sciences, v. 8, no. 1, p. 17-31, doi: 10.1016/0895-9811(94)00038-4.

Suárez, M., and Emparán, C., 1997, Hoja Curacautín. Regiones de la Araucanía y del Bío Bío: Carta Geológica de Chile: Santiago, Servicio Nacional de Geología y Minería de Chile, v. 71, p. 105, scale 1:250,000, 1 sheet.

Uliana, M., Dellape, D., and Pando, G., 1973, Estratigrafía, estructura y posibilidades petroleras del extremo noroeste de la Provincia de Neuquén: Buenos Aires, Yacimientos Petrolíferos Fiscales Open-File Report.

Varekamp, J.C., Maarten deMoor, J., Merrill, M.D., Colvin, A.S., Goss, A.R., Vroon, P.Z., and Hilton, D.R., 2006, this volume, Geochemistry and isotopic characteristics of the Caviahue-Copahue volcanic complex, Province of Neuquén, Argentina, in Kay, S.M., and Ramos, V.A., eds., Evolution of an Andean margin: A tectonic and magmatic view from the Andes to the Neuquén Basin $\left(35^{\circ}-39^{\circ} \mathrm{S}\right.$ lat): Geological Society of America Special Paper 407, doi: 10.1130/2006.2407(15).

Vattuone, M., and Latorre, C., 1998, Caracterización geoquímica y edad K/Ar de basaltos del Terciario superior de Aluminé, Neuquén, in Proceedings, 5th Congreso Latinoamericano de Geología: Buenos Aires, Servicio Geológico Minero Argentino, v. 2, p. 184-190.

Zapata, T., and Folguera, A., 2005, Tectonic evolution of the Andean fold and thrust belt of the southern Neuquén Basin, Argentina, in Veiga, G.D., Spalletti, L., Howell, J.A., and Schwarz, E., eds., The Neuquén Basin: A case study in sequence stratigraphy and basin dynamics: Geological Society of London Special Publication 252, p. 37-56.

Zapata, T., Brissón, I., and Dzelalija, F., 1999, The role of basement in the Andean fold and thrust belt of the Neuquén Basin, in Proceedings, Thrust Tectonics (third): London, University of London, p. 122-124.

MANusCript ACCEPTEd By THE SOCIETy 22 DeCEMBER 2005 